\title{
Sustainable Power Generation by Tidal Current Turbine in Straits of Malacca
}

\author{
P. T. Ghazvinei ${ }^{1}$, H. H. Darvishi ${ }^{2}$, A. Bhatia $^{3}$ \\ ${ }^{1}$ Department of Civil Engineering, Technical and Engineering College, Ale Taha Institute of Higher Education, Tehran, Iran, Email: \\ p.taherei@gmail.com \\ ${ }^{2}$ Department of Civil Engineering, Engineering and Management of Water Resources, Shahr-e-Qods Brach, Islamic Azad University, Tehran, \\ Iran, E-mail: hhassanpour87@gmail.com \\ ${ }^{3}$ Department of Civil Engineering, Faculty of Engineering, University of Malaya, 50603 Kuala Lumpur, Malaysia, Email: \\ aalisha9990@gmail.com
}

\begin{abstract}
Marine current power is a significant energy resource which is yet to be exploited for efficient energy production. Malaysia, being a tropical country is rich in renewable sources and tidal power is one of them. In Malaysia, Straits of Malacca is a potential site to establish a tidal current turbine. In the current study, the potential sites of the Straits of Malacca are discussed. A detailed review about the generator suitable for the Straits of Malacca with the associated challenges has also been discussed. Furthermore, the suitable solution for such challenges is proposed. The role of simulation in choosing an appropriate site and generator has also been reviewed. The focus of the study is to propose a generator suitable for the flow characteristics of the Straits of Malacca.
\end{abstract}

\section{Introduction}

Marine energy has become an issue of significant research achieving a spectacular increase in the last years [1]. Studies reveal that the theoretical potential of oceans using different techniques can produce 20,000 TWh to $92000 \mathrm{TWh}$, however, the energy demand of our planet is 16000 TWh [2]. Hence, oceans alone are capable of meeting the electricity demand of the whole planet. It is currently the focus of much industrial and academic research around the world [3]. Indeed, the astronomic nature of this resource makes it predictable, to within $98 \%$ of accuracy for decades which makes it more reliable than wind and solar energy [4]. This predictability is critical for the successful integration of renewable energy in the electrical grid. There are various ways to extract energy from oceans: Saline gradient temperature gradient tides, waves and tidal currents [5] are the prominent ones.

Malaysia is a tropical country in South-east Asia. It is rich in both renewable and non-renewable resources. The potential and the amount of electricity produced in Malaysia by various resources have already been discussed elsewhere. Malaysian government has done various efforts in the area of renewable and sustainable resources. In the 8th Malaysian plan, it has introduced renewable energy as the fifth fuel. Presently, Malaysia is highly dependent upon non-renewable sources for electricity production. However, owing to the negative impacts and the limited reserves of fossil fuels it has also started exploring the renewable sources. Malaysia is rich in biomass (palm oil), solar energy, wind, and marine energy. The resource map of Malaysia is discussed in [6].

Researchers have worked on the various resources available in Malaysia and marine energy is one of them Studies on the potential sites in Malaysia to install tidal current turbine had been conducted. Three out of four potential sites are located in the Straits of Malacca (SoM). Hence, it is important to study about the crucial aspects to establish the tidal current turbine at this site. SoM is a water stretch between peninsular Malaysia and the Indonesian island of Sumatra. Figure 1 shows the location of SoM. SoM is famous for the heritage values and business development. The potential of SoM is found in literature. The site selection for the turbine installation has been studied in. Even after a lot of research on marine energy assessment in Malaysia only a few systems are practically tested. This is because of the lack of the study of technical aspects related to the field [7]. Therefore, the study of the generator for this site is crucial.

Generator is one of the important parts of the tidal current turbine. The selection of the generator is done on the basis of tidal current velocity, power produced and number of turbines. There are various methods to arrange the generator in tidal current turbine. That is, either one generator can be used for various turbines or a single generator can be used for each turbine. In this study, these factors and the associated challenges are discussed. The remedies for these problems are also proposed. Tides change direction in every 6-12 hrs depending on the types of tide. The rise and fall in the height of the tides and the 
change in direction cause instability in the produced power. This instability causes power fluctuations which is one of the major challenges for the generator of the tidal current turbine. Hence, a thorough study about the marine current generator, associated problems and solutions is required.

Selection of generator can be done by practical testing, simulation in laboratory and by using simulation software. Among all these three methods software testing is most convenient and cost-effective. Water velocity, wake effect, blade structure are the main factors which can be easily studied using simulations. The study of the wake effect helps in investigating the performance of the turbine farm. The electromagnetic field, response of the generated power, power fluctuations and other electrical factors can also be studied by using various software. In this study a brief discussion is made to review the role of simulations. However for the detailed discussion about the role of simulation techniques is made [8].
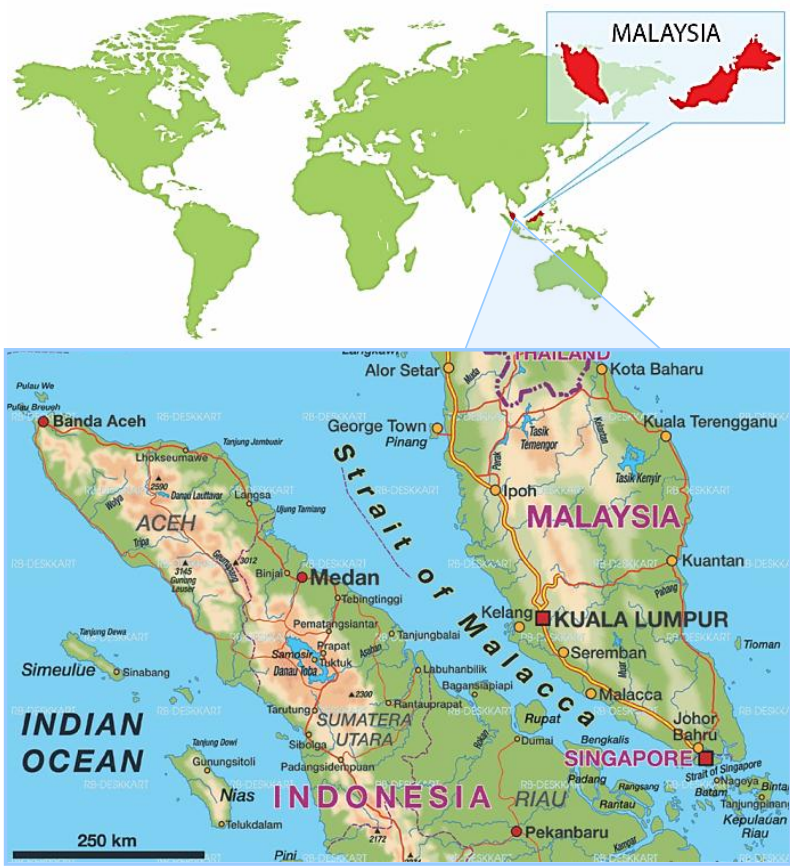

Figure 1. Geographical location of the Straits of Malacca.

The Straits of Malacca (SoM) is the longest international navigation route from the straits. It connects the Indian Ocean to the north with the South China Sea on the south via Andaman Sea and Straits of Singapore respectively. The straits is named after the Malacca Sultanate that ruled over the archipelago between 1400 and 1511. Fig 1 shows the geographical position of the Straits of Malacca. It is about 500 miles long, the width and depth varies from 11 to 200 miles and 10 to 70 meters respectively. The current flows in almost constant direction with the average current speed of $1-2 \mathrm{~m} / \mathrm{s}$ [9]. According to Peter Frankel the requirement of the site for tidal turbine is specific and the straits between islands \& main lands are suitable locations to install the tidal turbine [10]. Thus, SoM can be an appropriate location for the installation of tidal power plant for generating electricity.
A number of studies have been made to analyze the nature of SoM and to examine the impact of installing a tidal current turbine in it. A study also shows that the nature of SoM is tropical. However, the studies on the flow characteristics of the SoM are limited. The termination of various rivers in the SoM makes its environment similar to an estuary. This means SoM has low salinity, high spatial and temporal variation in many physical and chemical elements. In addition to this the SoM also have rich primary productivity and biodiversity. The hydro-graphic conditions of SoM are mainly because of the diurnal tides as well as by the northeast and southwest monsoons. The chemical \& biological conditions of the straits and the effect of human activities on the hydro-graphics and marine environment have been discussed. The investigation of the aforementioned factors indicates that bio-fouling will have a significant impact in the SoM. Research has been carried out to produce electricity from the SoM. The tidal current turbine is the most efficient way of extracting power from the SoM. It was found that the area around the Pangkor Island has steady current that moves northward for most part of the year with the current speed of $1-2 \mathrm{~m} / \mathrm{s}$ [11]. The speed may be variable as many rivers bring sediments which makes the straits shallower and reduces the speed. Another study was done using TPXO software to identify high stream current velocity sites in Malaysia. The study was carried out to test the main spots in Malaysia with highest tidal speed. There were 4 main sites in Malaysia: Sarawak, Pankgor Island, Malacca and Klang. Three out of these four sites are part of the SoM.

Pangkor Island, Malacca and Klang are the ports and islands of SoM. Among these three sites only Pangkor and Malacca seems to be appropriate options for establishing the turbines. The maximum velocity at these two sites is $2.4 \mathrm{~m} / \mathrm{s}$ and $1.8 \mathrm{~m} / \mathrm{s}$ respectively. The power output from the islands and ports of the SoM using the tidal stream approach were also studied in 2007 [7]. According to Lee and co-workers tidal turbine at Pangkor Island and Malacca can deliver power for 19 hours per day. As per the calculation done by Lee and co-workers the potential of SoM is to deliver 7.86 MW of power per year. However, the extractable power will be lower than this. Hence, a further detailed study on these sites will be helpful in determining an appropriate site for the installation of tidal turbine.

\section{Tidal Current Turbine Generator}

The potential of marine energy has attracted the attention of various industrial and academic researchers. The review about the tidal current turbines has been made in. Studies are being made on different turbine designs, to reduce the problem of sea scouring, to ease the procedure of installation and transportation and to improve the overall efficiency. Along with all the aforementioned factors, generators also play a vital role in the working and efficiency of the turbine. The selection of generator depends upon the available water velocity, nature of tides and the energy output [12]. Along with the limited studies on the flow characteristics of the SoM, no study up to 
date has been done to select a suitable generator for this straits.

One research group from Upsalla University in Sweden is working on the low speed tidal current generator and suggested that the direct drive permanent magnet synchronous generator (PMSG) is an optimum solution for the sites with low water velocity. Most of the research from this group is for vertical axis tidal current turbine. According to a study by this group of researchers the iron losses for generator are more than the copper losses for low velocity sites. Ben Elghali and co-workers from France have been actively working on the horizontal axis tidal current turbine generator. Ben Elghali and coworkers suggest that the PMSG has better power control option for horizontal axis marine current turbines compared to the doubly fed induction generator (DFIG). Elghali proved this by introducing the second-order sliding mode control that takes into consideration the turbulence and swell effects of marine current flow. However, it is remarkable to note that most of the installed turbines used the induction generator [13].

In this study generators are classified into two main categories: alternating current (AC) generators (synchronous and asynchronous) and direct current (DC) generators.

\subsection{Generator}

In later half of the eighties, it was proposed to have a power system with 3-phase, $50 \mathrm{~Hz}$ A.C generation, transmissions and distribution networks. Once A.C system was adopted the transmission of large power (MW) at higher transmission voltage became feasible by using transformers. Level of voltage could be changed virtually to any other desired level with a transformer which was hitherto impossible with D.C system. This is the reason that A.C generator is used in power generation in place of D.C generators [13]. The absence of commutators in A.C generators makes the construction simpler.

\subsection{AC Generator}

The generator which produces alternating power is known as a.c. generator. The usage of generator for tidal current turbine is not specific and varies as per the requirement of the site. SeaGen, SeaFlow and Kinetic hydropower system tidal current turbines used induction generator while Encurrent turbine and Cycloidal turbine used synchronous generator. Kobold and Gorlov turbines used both induction and synchronous generator. For better understanding A.C generators are classified into two categories: Induction (Asynchronous) generators and Synchronous generators [13].

\subsection{Induction generators}

These generators use the principle of electromagnetic induction for power generation. In such generators the rotor rotates faster than the synchronous speed and thus has a negative slip. These generators mostly require initial external excitation. This can be done by connecting it to the electrical grid. However, such generators can be made self-excited by using phase correcting capacitors.
Induction generator has various advantages: no voltage regulation, voltage and frequency are controlled by the utility, excitation is provided by the utility, synchronization of the generator with the system is not hampered by large power swings and simple construction with no brushes [13].

These are of two types singly fed and doubly fed induction generators. The main difference between these two generators is the single fed induction generator is self-excited while the DFIG requires external excitation. Even if DFIG is not self-excited its use is common in the renewable industry especially for power generation by wind turbine. The reason can be attributed to the constant amplitude and frequency of the output power. It is remarkable to note that the working of both the wind and tidal current turbine is similar but the density of air is 1000 times lower than that for water. This is the reason that the wind velocity in the range of $5-14 \mathrm{~m} / \mathrm{s}$ is required for power generation while it is $1-3 \mathrm{~m} / \mathrm{s}$ for tidal current turbine [14].

\subsection{Synchronous generator}

The other class of generator is synchronous generator. A synchronous generator consists of a stator containing a three-phase winding with each of individual phases positioned $120^{\circ}$ apart, and a rotor containing a field winding which is magnetized by direct current. This current can either be drawn from a brush exciter, brushless exciter or from the grid. The synchronous generator rotates at a constant speed at steady state. Controlled reactive power and fixed speed regulation are the major advantages of synchronous generator. Synchronous generator supplies reactive power rather than absorbing it which is the key significance of such generators. The supply of reactive power increases the apparent power and thus the power factor of the system. A small change in the value of power factor has a major impact on the system stability and cost [15].

Synchronous generator is of four types: Permanent magnet, wound rotor, salient pole and cylindrical rotor synchronous generator. From these four types, cylindrical rotor synchronous generator are beneficial for high speed applications like steam generators. Thus these are not applicable for marine technology where the speed is low or medium. The usage of wound rotor is more inclined towards the traction systems. Salient pole and permanent magnets are widely used for the wind and tidal turbines. However, the cost of PMSG is higher than the salient pole synchronous generator (SPSG). The reason can be attributed to the usage of rare earth magnets, which are expensive. The difference in the cost and the performance of permanent magnet and salient pole generators is explained [16].

In the current study the focus is on the low speed generators. Both PMSG and SPSG can be used for low current speed [16] and use classic three phase windings. However, PMSG have high flux density, high torque, high acceleration, easy launch and high efficiency [17]. PMSG are well known with the advantages of no field winding, slip-rings and exciter generator, avoiding heat dissipation in rotor and providing over-all efficiency and 
the removal of the conductor losses of the rotor conductor [16]. Earlier PMSG were used for low or medium power generation but because of above advantages now these are frequently used for high power generation [17] also.

Efficiency and output of PMSG is higher than the SPSG. A comparison of the efficiency and cost of both the generators have been made [16]. After the analysis, it is understood that while the efficiency of the SPSG is lower than the PMSG's, the SPSG is more economical in terms of cost and the electronic drive circuits used to control the machines. Even though the use of PMSG may be advantageous in lower power applications, SPSG may be more advantageous in high power applications with a better design factor.

Additionally, the processing and disposal of rare earth materials is not environmental friendly [17]. It also has the disadvantages of limited flux density regardless of high coercivity, core saturation and poor electronic control reliability. The use of PMSG is inclined more towards high efficiency, low current velocity and light weight turbine whilst the use of SPSG is more favourable for medium water current sites and is more environmental friendly during disposal. However, the water velocity plays an important role in the selection of generator. Thus PMSG with the direct drive system seems to be a suitable choice for the SoM. Nevertheless, a more in-depth study and experimentation on this will led to a more evident solution for this.

\section{Challenges for the tidal current turbine generator}

In Section 3, the selection of generator based on the requirements is explained. However, there are various challenges for the tidal turbine generator. The impact of these varies for ocean water and tropical straits water. These challenges are discussed in detail in the below sections and the effect on different type of water is compared in table 1 . The impact of power fluctuation will be lower for SoM as the speed of water is constant in the same direction, however, it is variable in case of oceans. This is the reason that it will be easier to control the output power from the generator installed at the SoM. The chemical composition of water effect the turbines parts exposed to water by causing corrosion and bio-fouling. Salinity of SoM is lower than ocean water; however, due to the presence of various organic components biofouling will be higher for SoM. The effect of heating of the windings depends upon the load and hence it is site dependent.

Table 1. Response of tropical and cold water towards various challenges.

\begin{tabular}{|c|c|c|}
\hline Challenges & Tropical Water & Cold Water \\
\hline Power fluctuations & Lower & Higher \\
\hline Corrosion & Higher & Lower \\
\hline Control System & Easy to control & Difficult to control \\
\hline $\begin{array}{c}\text { Heating of } \\
\text { windings }\end{array}$ & Site dependent & Site dependent \\
\hline
\end{tabular}

\subsection{Power Fluctuations}

Power fluctuation is one of the major problems for power generated by renewable sources (tidal current turbines) and makes the grid integration difficult. These fluctuations are due to the swells and direction change of the tides [18]. There are two types of power fluctuations: short-time scale and long-time scale power fluctuations. Large time scale power fluctuations occur after six or twelve hours and are mainly because of the astronomical phenomenon. These fluctuations are predictable and depend upon flood and ebb tide, tidal speed, tidal acceleration, water depth, turbulence strength and intensity.

Small scale power fluctuations occur for a few seconds and are produced due to the swell effect. Swells are the waves which are travelled over a long distance after its area of generation. The marine current speed fluctuation by underwater swells is considerable. In contrast to this, long term power fluctuations influence the generation reserves and energy dispatch of the power system while short term power fluctuations influence the power system frequency control [18]. The short term power fluctuations have high frequency while the long term power fluctuations persist for a long time. The solution for this problem has been discussed in the later sections.

\subsection{Corrosion}

Sea water is a corrosive medium. The effect of corrosion on the parts of tidal turbines has been studied by many researchers as an important consideration for tidal turbine [14]. Generator of the tidal turbine is either completely or partly immersed in water. Hence, a protective coating should be applied on the winding of the generator. This prevents the untimely outages. There are various materials available for this purpose [19]. However, the effect of insulations on the electrical, mechanical and thermal characteristics of the generator is still under investigation.

\subsection{Control systems}

Control system is required to monitor and regulate the output power of the tidal current turbine. The control system helps to maintain an optimum speed of the generator so that maximum power can be harnessed from the turbine. According to Mbabazi for a particular water velocity there is always a rotor speed that produces maximum power. Few other researchers have also stated the same for wind and tidal turbines. The control system should be capable of protecting the system from over power. The effect of over power on the torque and rotational speed of the rotor for PMSG in case of wind turbines is discussed in [19]. The impact of over power in case of tidal turbine will also be similar as the same generator will be used.

The load characteristics regulate the torque characteristics for both the generator and turbine. Hence, the control of the load characteristics is important in order to optimize the operation of turbine and generator. One way of controlling the load characteristics is by controlling the current. The method of doing this is 
discussed in [19]. The results are also verified by simulating the same using Simulink.

\subsection{Heating of winding}

Tidal turbines which are installed for the commercial usage usually have large generators. The loading conditions of the turbine have an impact on its electrical, mechanical and thermal properties. The overloading of generator requires various measures as the cooling material is air which does not have heat transfer ability. Moreover, the windings of the generator rotor are confined in the steel slots and are subjected to temperature expansion problems. This is the reason that the tidal current turbine generator windings use various types of insulations. Hence, if overloading conditions are expected in a particular area which depends upon the power by tidal current various tests should be performed on the generator windings. These tests including with the results are discussed [20].

\section{Proposed solution for the problems}

The aforementioned problems are the few major challenges for the tidal current turbine generators. In this section few solutions are provided for the problems encountered.

\subsection{Energy stabilisation}

As explained in section 4.1 the power fluctuation is either small scale, large scale or both. Hence, there is a need to supply and absorb energy as per the requirement. The energy storage techniques used for marine current turbines have been explained [21]. The usage and the pros-cons of energy storage system by batteries and other methods have been done in table 2 and 3 respectively. The large scale fluctuations can be stabilized by battery storage systems, however, for small scale fluctuations the methods proposed in table 3 are more effective. Another method of stabilizing the power is increasing the power factor. A study has been done to analyze the power fluctuations in an established tidal current turbine in Seagen. The results show that the power fluctuation for Seagen was only because of the variation in tidal speed and the effect never exceed $1.25 \%$ for voltage and $0.65 \%$ for current. The study also says that the high power factor (0.99) helps to minimize the effect of power fluctuation. The problem of power fluctuation is common for all the renewable sources. As stated earlier the working principle of both wind and tidal turbine is the same. A novel technique of stabilizing the power for wind turbine was invented by Mohammad Lutfur Rahman and co-workers. The authors explained that the tidal turbine with an induction generator can be used as a motor or generator depending upon the requirement which will charge and discharge energy like a flywheel and this system will be connected after the wind turbine using a synchronous generator. The performance of this technique was verified by using a mathematical simulation on PSCAD. Mohammad Lutfur Rahman in the same study has also stated that the tidal power is more stable than wind energy and IGBT (insulated gate bipolar transistor) converters can be used for power stabilization. It is remarkable to note that IGBT's are used in removing the fluctuation in case of Seagen [21].

As the water of SoM does not have high variation in water velocity compared to oceans, hence, the use of IGBT converters can minimize the effect of power fluctuations.

\subsection{Prevention of corrosion}

As discussed in the previous sections the salinity of SoM is lower than the sea water. However, the presence of various chemicals increases the chances of bio-fouling and makes the environment harsh for tidal current turbines. As per Bahaj and co-workers this can be prevented by enclosing the generator parts in a nacelle and sealing it properly. Coating of the various components by paint and increasing the thickness of the parts also helps in the prevention of corrosion [14].

\subsection{Control strategies}

Control strategies are important for all the power generation systems. In case of tidal turbine no case of system failure has been reported due to poor generator control strategies. However, there is a case of whole turbine failure due to high speed tidal currents. This may have a serious impact on the working and efficiency of the generator. Depending upon the type of generator and the site velocity, various control strategies can be used. Including with this the connected load also plays a vital role to decide the appropriate control strategies. The deeper study on this has been made by various researchers [22].

\subsection{Cooling method}

The windings of generator are mainly heated up during the overloading conditions. Including with this for cost cutting the cross sectional area of the conductor, thickness of the insulator, and material in the steel core are reduced. This factors leads to the heating of the generator winding. The conditions for overloading also lead to the heating up of the windings. However, if proper measures are taken then this problem can be controlled to a great extent.

Table 2. Pros and Cons of various battery type energy storage system.

\begin{tabular}{|c|c|c|}
\hline $\begin{array}{c}\text { Battery } \\
\text { Type }\end{array}$ & Pros & Cons \\
\hline $\begin{array}{l}\text { Lead acid } \\
\text { [23] }\end{array}$ & $\begin{array}{c}\text { easy installation } \\
\text { low cost } \\
\text { negligible maintenance } \\
\text { low self-discharge rate } \\
\text { (2-5\% the rated value) } \\
\text { ideal for long term } \\
\text { storage }\end{array}$ & $\begin{array}{c}\text { low energy } \\
\text { density }(30 \mathrm{wh} / \mathrm{kg}) \\
\text { short service life } \\
(1200-1800 \\
\text { cycles }) \\
\text { Temperature } \\
\text { dependent } \\
\text { batteries } \\
\text { not suitable for } \\
\text { discharge over } \\
20 \%\end{array}$ \\
\hline Nickel & longer life time $(3000$ & high cost \\
\hline
\end{tabular}




\begin{tabular}{|c|c|c|}
\hline $\begin{array}{c}\text { based } \\
\text { (Nickel } \\
\text { Cadmium) }\end{array}$ & $\begin{array}{l}\text { cycles) } \\
\text { fully dischargeable }\end{array}$ & $\begin{array}{l}\text { toxic components } \\
\text { of Cadmium [24] }\end{array}$ \\
\hline $\begin{array}{l}\text { Nickel } \\
\text { based } \\
\text { (Nickel- } \\
\text { metal } \\
\text { hydride) }\end{array}$ & $\begin{array}{l}\text { high energy density } \\
\text { work over high } \\
\text { temperature range }\end{array}$ & $\begin{array}{l}\text { life cycle will be } \\
\text { shorten by their } \\
\text { repeatedly } \\
\text { discharge on high } \\
\text { load current [25] }\end{array}$ \\
\hline $\begin{array}{l}\text { Nickel } \\
\text { based } \\
\text { (Nickel- } \\
\text { zinc) }\end{array}$ & $\begin{array}{c}\text { deep cycle capabilities } \\
\text { high energy density } \\
{[26]}\end{array}$ & $\begin{array}{l}\text { life cycle is } \\
\text { hampered by the } \\
\text { growth of the } \\
\text { dendrites }\end{array}$ \\
\hline $\begin{array}{l}\text { Lithium } \\
\text { ion }\end{array}$ & $\begin{array}{c}\text { high energy density (90 } \\
\text { to } 190 \mathrm{Wh} / \mathrm{kg} \text { ) } \\
\text { high power density } \\
\text { (500 to } 2000 \mathrm{Wh} / \mathrm{kg} \text { ) } \\
{[27]} \\
\text { low self- discharge }\end{array}$ & $\begin{array}{c}\text { actual efficiency is } \\
\text { lower than } \\
\text { theoretical } \\
\text { fragile } \\
\text { difficult } \\
\text { maintenance } \\
\text { high cost }\end{array}$ \\
\hline $\begin{array}{l}\text { Sodium } \\
\text { sulphur }\end{array}$ & $\begin{array}{l}\text { high energy density } \\
\text { (100 Wh/kg } \\
\text { highly efficient at high } \\
\text { temperature } \\
100 \% \text { depth of } \\
\text { discharge } \\
\text { low cost } \\
\text { high efficiency } \\
\text { deep discharge } \\
\text { tolerance } \\
\text { efficiency between } \\
75 \% \text { to } 90 \% \\
\text { average cycle life of } \\
2500[28]\end{array}$ & $\begin{array}{l}\text { corrosive nature of } \\
\text { sodium } \\
\text { high operating } \\
\text { temperature }\end{array}$ \\
\hline $\begin{array}{c}\text { Flow } \\
\text { batteries } \\
{[29]}\end{array}$ & $\begin{array}{l}\text { power and energy } \\
\text { ratings can be sized } \\
\text { independently } \\
\text { long service life (about } \\
10,000 \text { cycles at } 75 \% \\
\text { depth of discharge) } \\
\text { high safety } \\
\text { negligible degradation } \\
\text { for deep discharge } \\
\text { negligible self- } \\
\text { discharge }\end{array}$ & $\begin{array}{l}\text { Complexity } \\
\text { High cost }\end{array}$ \\
\hline
\end{tabular}

Table 3. Various types of energy storage systems.

\begin{tabular}{|c|c|c|}
\hline $\begin{array}{l}\text { Energy Storage } \\
\text { System }\end{array}$ & Advantages & Disadvantages \\
\hline Flywheel & $\begin{array}{l}\text { Long service life } \\
\text { (105 cycles with } \\
\text { deep discharge) } \\
\text { High power } \\
\text { density } \\
\text { High efficiency } \\
\text { Low maintenance }\end{array}$ & $\begin{array}{l}\text { High self- } \\
\text { discharge } \\
\text { High cost }\end{array}$ \\
\hline Super Capacitor & $\begin{array}{c}\text { High energy } \\
\text { efficiency } \\
\text { Long service life } \\
(500,00 \text { cycles }) \\
\text { Wide temperature } \\
\text { range } \\
\end{array}$ & $\begin{array}{c}\text { High self- } \\
\text { discharge } \\
\text { Very low energy } \\
\text { density }(5 \mathrm{Wh} / \mathrm{kg})\end{array}$ \\
\hline $\begin{array}{l}\text { Pump Hydro } \\
\text { Storage system }\end{array}$ & $\begin{array}{l}\text { High efficiency } \\
\text { (up to } 75 \% \text { ) } \\
\text { High power } \\
\text { storage }\end{array}$ & $\begin{array}{c}\text { Appropriate } \\
\text { geographic site } \\
\text { High cost } \\
\text { Long construction }\end{array}$ \\
\hline
\end{tabular}

\begin{tabular}{|c|c|c|}
\hline & $\begin{array}{c}\text { Favorable for load } \\
\text { levelling }\end{array}$ & time \\
\hline $\begin{array}{c}\text { Compressed air } \\
\text { energy storage }\end{array}$ & $\begin{array}{c}\text { Cost effective } \\
\text { High reliability } \\
\text { Power } \\
\text { smoothening }\end{array}$ & $\begin{array}{c}\text { Geological } \\
\text { dependence } \\
\text { Use of fossil fuel } \\
\text { Energy dissipation }\end{array}$ \\
\hline
\end{tabular}

\subsection{Role of Simulation}

Water turbines have complicated geometry. Thus, there are various factors which are considered before the selection and during the testing of generator used for a tidal current turbine. There are physical factors like marine current speed, electromagnetic fields and wakes. The other factors are the statistical factors like the voltage- current characteristics of the power harnessed, effect of the energy storage system on the output, deviation in power by using different generator to name a few. Study of the factors and situations can be done by using simulation software. Investigations of the physical factors (marine current speed, wakes, and electromagnetism) have been done by various researchers using a computational fluid dynamics software called OpenFOAM [30]. For the study of electromagnetism, partial discharge and losses a number of study has been done is still ongoing using the various software. The use of PSCAD, Matlab, and Opera is more common for the study of the response of electrical factors.

\section{Conclusion}

Marine current has the potential to generate electricity with a low negative impact on the surrounding environment. The sites of 'Straits of Malacca' like Pangkor Island and Malacca are capable of producing electricity which could supplement the energy needs of Malaysia and prevent the greenhouse gas emission. The velocity of the water is at these site is not high but with the use of direct drive permanent magnet synchronous generator the desired output can be achieved. High biofouling in the tropical water can be regulated by coating the generator parts and turbine with optimum materials. Simulation and numerical modelling will help in achieving better results without wasting the resources. Being a tropical water site the challenge of power fluctuation will be lower for SoM and can be controlled by using IGBT. The research going in the various parts of the world has great advantage regarding the slow velocity sites. The deployment and testing of a tidal current turbine at this site will serve as a milestone for the similar future projects.

\section{References}

1. Fergal RO, Boyle F and Reynolds A. Marine current energy devices: Current status and possible future applications in Ireland. Renewable and Sustainable Energy Reviews April 2010; 14 (3): 1026-1036.

2. Esteban M, Leary D. Current developments and future prospects of offshore wind and ocean energy. Applied Energy February 2012; 90 (1): 128-136. 
3. Henrey J, Jay B, Winskel M. Accelerating the development of marine energy: Exploring the prospects, benefits and challenges. Technological Forecasting and Social Change April 2012; 23.

4. Julio V, McKesson C, Walczak M. Sustainable energy for the marine sector. Energy Policy October 2012; 49: 333-345.

5. Hassan HF, Karim OA, Al-Shafie E. Tidal current turbines glance at the past and look into future prospects in Malaysia. Renewable and Sustainable Energy Reviews October 2012. 16 (8): 5707-5717.

6. Chen WN. Renewable Energy Status in Malaysia. Sustainable Energy Development Authority Malaysia December 2012; Malaysia.

7. Andaya LY. Leaves of the Same Tree: Trade and Ethnicity in the Straits of Melaka. University of Hawaii Press 2008; USA.

8. Ramos V, Carballo R, Álvarez M, Sánchez M, Iglesias G. Assessment of the impacts of tidal stream energy through high-resolution numerical modelling. Energy 2013.

9. National Geospatial-Intelligence Agency. Sailing directions-Strait of Malacca and Sumatera 2013; Springfield, Virginia.

10. Frankel PL. Tidal Current Energy Technologies. International journal of avaian science- IBIS March 2006; 148 (s1): 145-151.

11. Looi LJ, Aris AZ, Johari WLW, Yusoff FM, Hashim Z. Article in Press. Baseline metals pollution profile of tropical estuaries and coastal waters of the Straits of Malacca. Marine Pollution Bulletin 2013.

12. $\mathrm{Ng} \mathrm{KW}$, Lam WH, Ng KC. 2002-2012: 10 Years of Research Progress in Horizontal-Axis Marine Current Turbine. Energies 2013; 6: 1497-1526.

13. Elghali B, Benbouzid SE, Benbouzid MEH, Charpentier JF. Generator Systems for Marine Current Turbine Applications: A Comparative Study. IEEE Journal of Oceanic Engineering 2012; 37 (3): 554-563.

14. Arief A, Dong ZY, Nappu MB, Gallagher M. Under voltage load shedding in power systems with wind turbine-driven doubly fed induction generators. Electric Power Systems Research March 2013; 96 : 91-100.

15. Machowski J, Bialek JW, BumbyJR. Power System components in Power Sytem dynamics. John Wiley and Sons Ltd 19-25. Published Online 1997.

16. Kömürgöz G, Gündogdu T. Comparison of Salient Pole and Permanent Magnet Synchronous Machines Designed for wind turbines. Power Electronics and Machines in Wind Applications (PEMWA), 2012 IEEE.

17. Ghiţă C, Chirilă AI, Deaconu ID, Ilina DI. Wind turbine permanent magnet synchronous generator magnetic field study. International Conference on Renewable energy and Power Quality 2007; Santander, Spain.
18. Jadhav HT, Roy R. A comprehensive review on the grid integration of doubly fed induction generator. International Journal of electric Power and Energy System July 2013; 49: 8-18.

19. Chinchilla M, Arnaltes S, Burgos JC. Control of Permanent-Magnet Generators Applied to VariableSpeed Wind-Energy Systems Connected to the Grid. IEEE Transactions On Energy Conversion March 2006; 21 (1): 130-135.

20. Judendorfer T, Fletcher J, Hassanain N, Mueller M, Muhr M. Challenges to machine windings used in electrical generators in wave and tidal power plants. IEEE- Electrical Insulation and Dielectric Phenomena 2009; 238-241.

21. MacEnri J, Reed M, Thiringe T. Influence of Tidal Parameters on SeaGen Flicker Performance. Philosophical Transactions of the Royal Society A: Mathematical, Physical and Engineering Sciences 2013; 371 (1985).

22. Zhou Z, Scuiller F, Charpentier JF, Benbouzid M, Tang T. Power Limitation Control for a PMSGBased Marine Current Turbine at High Tidal Speed and Strong Sea State. IEEE, 2013.

23. Culpin B. Secondary Batteries - LEAD- ACID SYSTEMS | Valve-Regulated Batteries: Oxygen Cycle. Reference Module in Chemistry, Molecular Sciences and Chemical Engineering, from Encyclopedia of Electrochemical Power Sources 2009; 705-714.

24. Espinosa DCR, Tenorio JAS. Recycling of nicklecadmium batteries- Thermogravimetric behaviour of electrodes. Journal of Power Sources 2006; 160 (1): 644-751.

25. Notten PL, Latroche M. Secondary batteries- Nickel system Nickel Metal Hydride: Metal hydrides. Encyclopedia of Electrochemical Power Sources 2009; 502-521.

26. Pavlov AP, Grigorieva LK, Chizhik SP, Stankov VK. Nickel-Zinc batteries with long cycle life. Journal of Power Sources 1996; 62 (1): 113-116.

27. Khaligh A, Alireza, Zhihao L. Battery,ultra capacitor,fuel cell,and hybrid energy storage systems for electric,hybrid electric,fuel cell,and plug-in hybrid electric vehicles: state of the art. Vehicular Technology, IEEE transaction 2010; 59 (6): 28062814.

28. Chen H, Cong TN, Yang W, Tan C, Li Y, Ding Y. Progress in electrical energy storage system: A critical review. Progress in Natural Science March 2009, 19 (3): 291-312.

29. Dunn B, Kamath H, Tarascon JM. Electrical Energy Storage for the Grid: A Battery of Choices. Science 18 November 2011; 334 (6058): 928-935.

30. Higuera P, Lara JL, Losada IJ. Simulating coastal engineering processes with OpenFOAM®. Coastal Engineering, January 2013; 71: 119-134. 